\title{
Unsustainable management of wastewater and brewing effluents: The impacts on socio- economy and environment, Lagos and Niger Delta region, Nigeria
}

\author{
Oruche Henry Chukwuma ${ }^{1 *}$ and Okpara Donatus Anayo ${ }^{2}$ \\ ${ }^{1}$ Department of Innovation management in the production industry, People's Friendship University of \\ Russia (RUDN University) 6 Miklukho-Maklaya Street, Moscow, 117198, Russian Federation \\ ${ }^{2}$ Department of Environmental Monitoring and Forecasting, People's Friendship University of Russia \\ (RUDN University) 6 Miklukho-Maklaya Street, Moscow, 117198, Russian Federation
}

\begin{abstract}
Wastewater mismanagement poses a threat to economic growth and long term prosperity of many countries around the world specially developing ones. Waste is regarded as redundant products, with no marginal value by the owner but impact negatively to the environment and human well-being. Wastewater treatment or reuse does not only improve the promotion of environment and healthy ecosystems but sustains it for long period. Sustainable wastewater management is crucial especially in Niger Delta where water scarcity is enormous. Socio-economic importance of wastewater control especially by municipals, brewery and industries cannot be overemphasized. Though combinations of effluents, oil spills, etc. contribute over $95 \%$ of environmental pollution in Nigeria, our focus is on inefficiency of wastewater treatment plants. This study examines the exposure of poor management of wastewater, brewery effluents in Niger delta eco-zones and Lagos state. Multiple Exposure, Multiple Effects (MEME) descriptive method of analysis was used. Based on expository founding that humans, flora and fauna were exposed to the danger of wastewater pollutions in both regions. Conclusion was made based on government priority. The study will be beneficial to brewery industries, government monitoring agencies/institutions, researchers for further improvement especially in the area of mind-set change.
\end{abstract}

* Corresponding author: donatusokpara@yahoo.com 


\section{Introduction}

Global water consumption has been on the rise as the world's population keeps growing. The main water consumers are Industries, Municipal and Agriculture to sustain life on earth. According to Shiklomanov [1], the global water consumption in the $21^{\text {st }}$ century from a withdrawals perspective shows that about $70 \%$ of water is used for agriculture (irrigation), $20 \%$ of the total global withdrawals is attributed to industries while municipal usage accounts for $10 \%$. This proportion of global usage can be observed in most countries. The water withdrawal or water consumption by humans in Nigeria follows a similar trend, with the majority of the usage attributed to agriculture (irrigation, livestock, Aquaculture). Fig. 1 shows the proportion of water withdrawal usage in Nigeria.

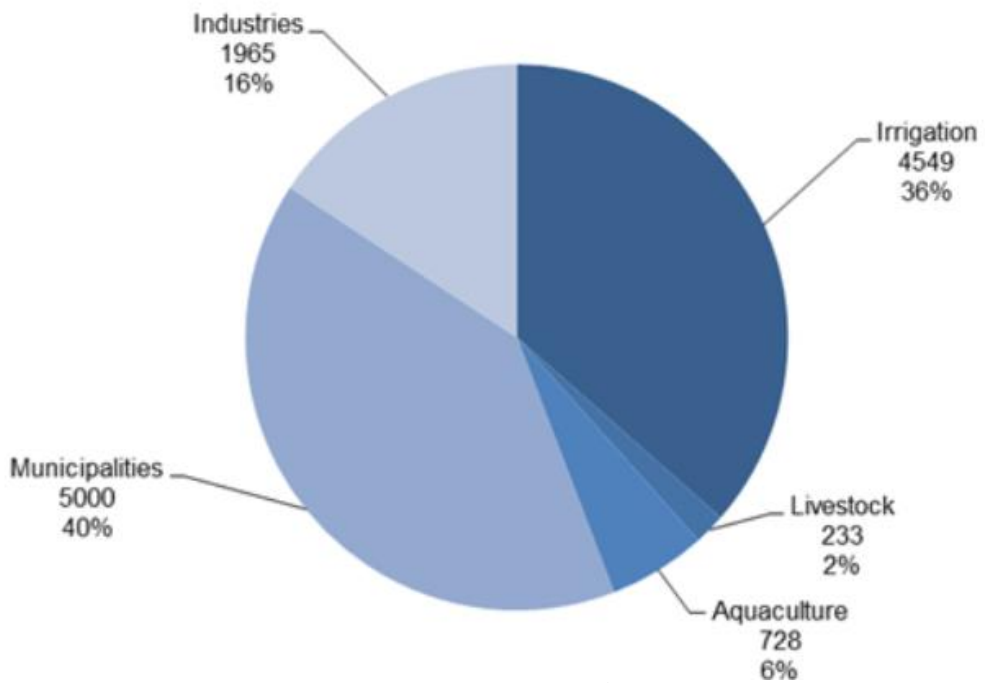

Fig. 1. Water withdrawal by sector, total 12475 million $\mathrm{m}^{3}$ in 2010 [2].

This paper focuses on the poor management of wastewater treatment plants in Lagos and Niger delta region, industrial water consumption by breweries and its effects on the environment, society and the ecosystem as a whole.

The declining state of wastewater treatment plants in Nigeria as a whole arouses anxiety and remains a fiction for more than thirty decades due to poor management and zero modernization. The sector is abandoned and the impact is fast increasing as it rains heavily in 2020. According to Nigerian meteorological agency [3] rain forecast is between 400mm in the North and up to $3000 \mathrm{~mm}$ in the South this year. The despicable state of the plants would surely continue to inject worries to the general public whose environmental challenges concerns raises social anxiety. All government declarations to revamp the collapsing sector are yet to cushion the worries of the public. Wastewater management in Nigeria is very poor and Lagos as well as the Niger Delta region is no exception. In Lagos alone, about $95 \%$ of the people have been estimated to have no access to sanitary systems. The current sanitary systems available in Lagos state comprises of government and privateowned facilities, however, but together they can provide only partial but insufficient treatment of wastewater. 
A report in the guardian newspaper July $6^{\text {th }}, 2018$ shows concrete evidence that the existing wastewater treatment plants infrastructure are insufficient and in a very poor state including the Federal owned wastewater treatment plants located in Festac / Satellite town, Gowon estate, trade fair complex, 1004 estate, Nigerian law school, PHCN thermal station (Egbin), University of Lagos, school of nursing (Obalende) and Muritala Mohammed airport and the Lagos state wastewater management treatment plants at Abesan, Oke-afa and Iponri are not functional. More so, there was a public outcry for a possible outbreak of epidemic recently raised by the residents of Jakande housing estate, and Isolo around okeafe wastewater plant in Lagos due to visible effluent from pipes overflowing into the streets and drainage system. Most of this plant with a capacity to serve 40 to 50 thousand people has been in operation since 1982 with activated sludge technology performing the primary, secondary and tertiary treatment. Meanwhile, Niger Delta (ND) is the heart of crude oil processing zone and petrochemical industries discharge a significant amount of wastewater to the environment. Report by Veil et al [4] estimated about 14 billion barrels of water annually in the region. According to Suleimanov [5] such waste contained large quantities of toxic chemicals, polycyclic crude oil products and other hydrocarbons. We can postulate that the 3 oil refinery industry in ND commissioned in 1965, 1978 and 1991 with 30\% capacity production of $60,000 / 9450,150,000 / 24000$, and $125,000 / 19900 \mathrm{bbI} / \mathrm{day} / \mathrm{M}^{3} / \mathrm{day}$ respectively do not have sufficient wastewater treatment plants or modern technology to remove pollutants Kadafa et al [6]. Where such is the case, the environment is directly affected. There is experimental evidence that showed positive corrections between pollution from refinery effluents, marine organism's health by Marcus and Ekpete [7] and heavy metals on water bodies, soil and sediments according to Okpara et al [8], Okpara and Kharmova [9] Okpara and Effiong [10].

Some of the major industries with the highest water consumption are the food industry and oil refinery. Within this industry, the beverages and brewing industry withdraws a lot of water for production. Behind milk, coffee, tea and carbonates, beer is considered the most consumed beverage with an average consumption per person of about 23 litres in a year. The brewing process is water consuming. Beer among other beverages contains about $95 \%$ of water. The rate of consumption of water during the brewing process is correlated to the effluent ratio, which is the amount of wastewater generated per production Fillaudeau et al [11].

\section{Method}

Multiple exposures, multiple effects (MEME) method was selected for this study because it enabled us to navigate the connecting interrelationship between the human vulnerability in the exposure- effects and social economic potential eventualities. As a cased based study, using literature materials and descriptive principles, we reviewed attributing indicators such as social, economic and eco-zone conditions among others and their impact on wellbeing, soil, ambient, environment etc, as combined unsustainable concerns requiring better design with an imminent intervention, effective measures adaption and mitigations actions in a long term basis. 


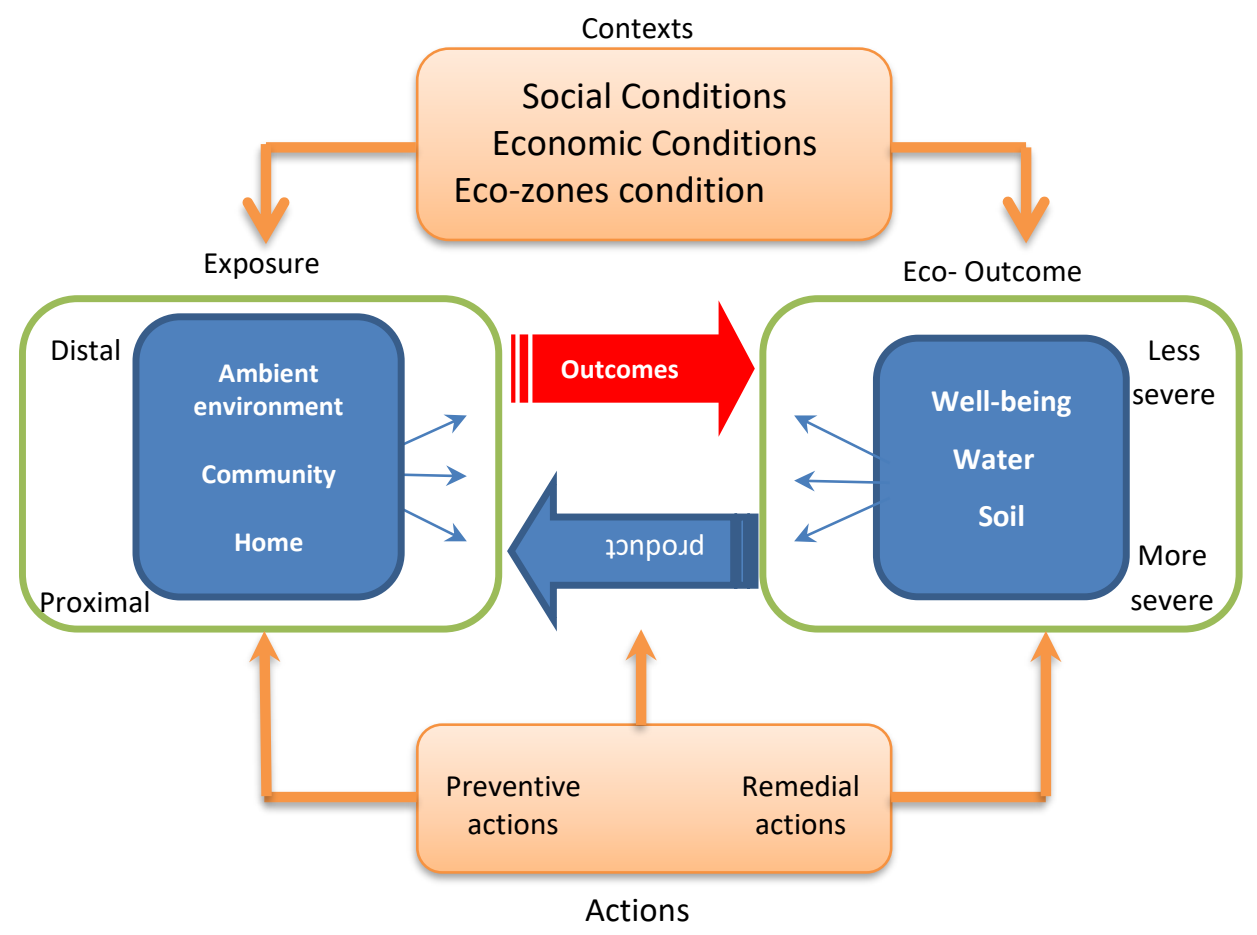

Fig. 2. MEME model [12].

\section{Results and discussion}

\subsection{Sources affecting water resources and ecology in Nigeria}

\subsubsection{The production process}

The fundamentals of the production process are generally similar for most breweries. The changes that may result in the process can be attributed to the size, the market, the type of brew and flavour. Common ingredients employed in the process include wheat, barley, sugar, hops, rice, yeast and water. A brewhouse is required for the malting process which is the first step in the brewing process. The process usually involves the soaking of the grains in water to enhance germination after which they are dried in a kiln before they go through milling, mashing, separation, boiling, coiling, fermentation, maturation \& pasteurization and finally packing. Fig. 2 provides a representation of the process. 


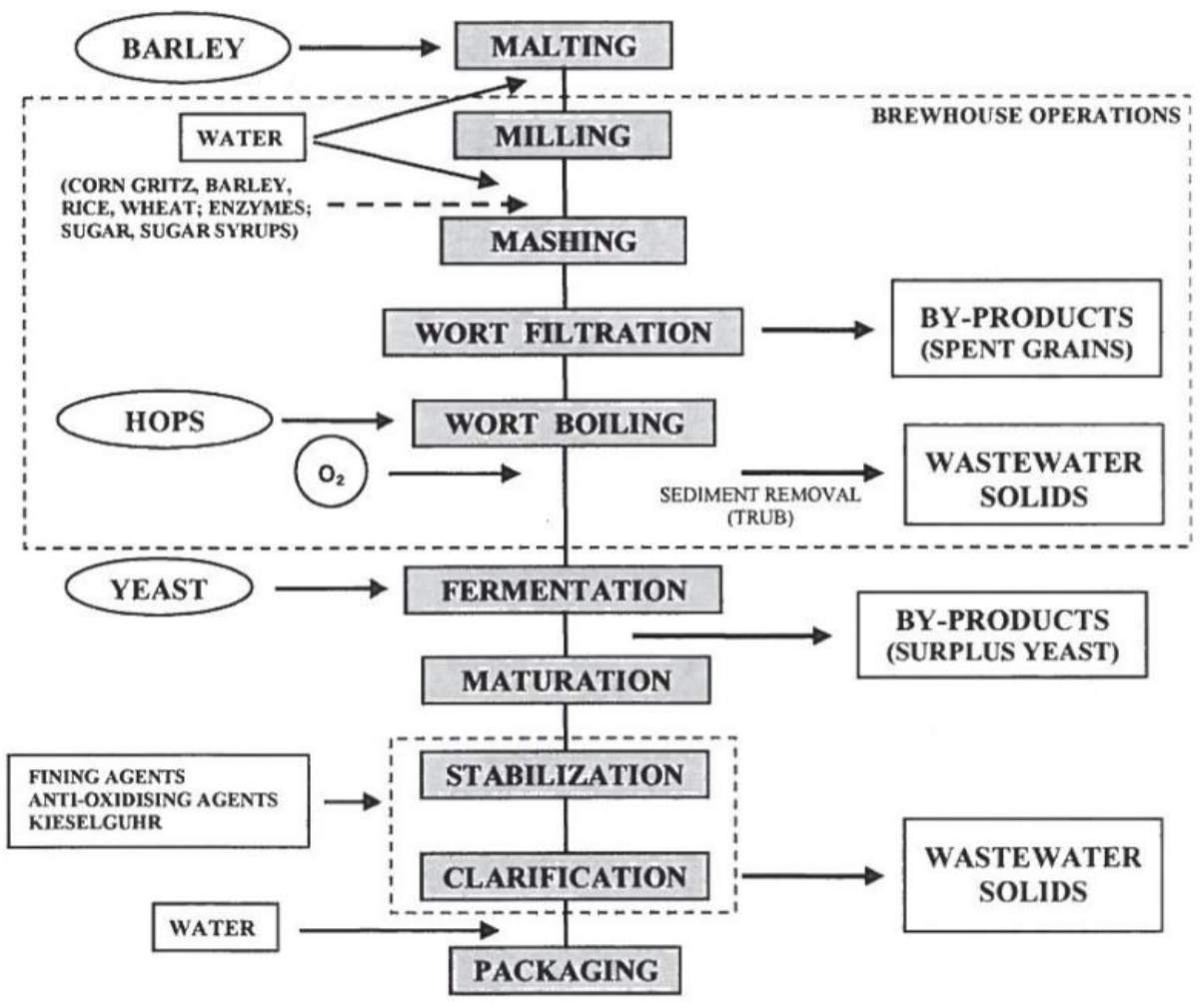

Fig. 3. The generic brewing processes for beer production $[13,14,15]$.

The water used in the brewing process is mostly lost in the by-product as wastewater (effluent). Wastewater is considered an important waste product of the process as it contains organic materials. These are sometimes recycled by some breweries or used in the generation of energy in biogas plants. It is, however, worthy of note that the effluent or liquid waste does not only come from the production process but also from water used for sanitation, cleaning, heating and cooling processes and most of all for production. Ase shown in Table 1, these processes lead to the production of waste in the form of solids, liquids (effluent) and gaseous waste. One of the most dominant wastes generated by the industry is liquid waste. According to Fillaude et al [16] most of the water used in the process ends up as effluent, however, the effluent load is quite similar to the water load.

Table 1. Main areas of wastewater generation in the brewing process [17].

\begin{tabular}{|c|c|}
\hline Source & Operation \\
\hline Mash Tun & Rinsing \\
\hline Lauter Tun & Rinsing \\
\hline Spent Grain & Last running and washing \\
\hline Boil Kettle & Dewatering \\
\hline Whirlpool & Rinsing spent hops and hot trub \\
\hline Fermenters & Rinsing \\
\hline Storage tanks & Rinsing \\
\hline Filtration & Cleaning, start-up, end of filtration, leaks during \\
\hline
\end{tabular}




\begin{tabular}{|c|c|}
\hline & filtration \\
\hline Beer spills & Waste, flushing, etc. \\
\hline Bottle washer & Discharge from bottle washer operation \\
\hline Keg washer & Discharge from keg washing operations \\
\hline Miscellaneous & Discharge cleaning and sanitation materials, etc. \\
\hline
\end{tabular}

\subsection{Discharging effluents}

An effluent is considered as wastewater or liquid discharged from industrial operations. They are either treated or untreated. Sources of effluents can be categorized as non-point or point source depending on the source of the pollutants. Non-point sources are usually untraceable; they include animal waste pollution, pollution from storms, soil erosion and chemical runoffs. Since their sources are untraceable they pose a major challenge to the management of water quality. Point source pollution on the other hand as the name suggests can be traced to a source. These sources are mostly agents that dispose of wastes or byproducts of their activities. These agents include industries, households and municipal waste treatment or management plants.

Untreated or sometimes treated effluents from point sources may carry toxic substances from the production process into the environment which affects the soil quality, air and water quality for the sustenance of living things. The disposal of the wastewater resulting from production poses a problem for the society as most breweries may not treat their wastes before disposal to cut down on the cost of disposal. Eckenfelder [18] suggests that treatment of the wastewater (using primary and secondary treatments) may help remove the unwanted industrial pollutants like heavy metals, soluble organics, nitrogen, suspended solids, and phosphorus before they are released into the environment. The receiving media could be in danger if the process is not handled well and some of the undesirable chemicals end up in the environment. This is the case in most developing countries especially the brewery sector in the Niger Delta and Lagos state. Ford [19] suggests monitoring and periodic sampling in case this happens to ensure the contaminants are under control and not in quantities that can harm the environment.

\subsubsection{Chemical components of brewery effluent}

Our point source effluent helps us decide appropriate treatment, disposal and reuse. A typical analysis of effluent at a temperature range of $130^{\circ} \mathrm{C}$ to $600^{\circ} \mathrm{C}$, according to Arceivala [20] will reveal constituents such as colloidal solids, dissolved solids and suspended solids. The main constituents of effluent include BOD, COD, TSS, Nitrogen and Phosphorous.

Table 2 below shows the typical characteristics of brewery effluent and their indicative discharge limits in the EU.

Table 2. Brewery effluents and discharge limits for EU standard.

\begin{tabular}{|l|l|l|l|}
\hline \multicolumn{1}{|c|}{ Parameter } & \multicolumn{1}{|c|}{$\begin{array}{c}\text { Brewery effluent } \\
\text { composittion }\end{array}$} & $\begin{array}{c}\text { Typical brewery bend } \\
\text { marks }\end{array}$ & $\begin{array}{c}\text { Limits (mg/l) } \\
\text { (Discharge standards) }\end{array}$ \\
\hline Flow & & & \\
\hline COD & $2000-6000$ & $2-8 \mathrm{hl}$ effluent/hl beer & 125 \\
\hline BOD & $1200-1000$ & $0.5-3 \mathrm{~kg} \mathrm{COD} / \mathrm{hl}$ beer & 25 \\
\hline TSS & $200-1000$ & $0.2-2 \mathrm{~kg} \mathrm{BOD} / \mathrm{hl}$ beer & 35 \\
\hline T & $18-40$ & $0.1-0.5 \mathrm{~kg}$ TSS $/ \mathrm{hl} \mathrm{beer}$ & \\
\hline
\end{tabular}




\begin{tabular}{|l|l|l|l|}
\hline PH & $4.2-12$ & & \\
\hline Nitrogen & $25-80$ & & $10-15$ \\
\hline Phosphorus & $10-50$ & & $1-2$ \\
\hline
\end{tabular}

Source: Driessen and Vereijken [21].

Organic component in brewery effluent is expressed as chemical oxygen demand and biological oxygen demand. Brewery solids are also expressed as TSS; these as earlier mentioned. According to Driessen and Vereijken, [21], removal of COD before disposal is vital to prevent anaerobic conditions in the receiving waters from the point source.

Heavy metals such as Aluminum (Al), Cyanide (CN), Mercury (Hg), Manganese (Mn), and Cadmium $(\mathrm{Cd})$ are sometimes found in wastewater, indicating the toxicity of the receiving medium. These metals are a threat to biological organisms and can sometimes hinder the proper functioning of some biological treatment plants. It is therefore very important to consider all these elements when assessing brewery effluents.

\subsubsection{Impact of effluent on the environment}

The food and beverages (including breweries) as mentioned earlier is one of the major industry categories in Nigeria. The location of some of the major breweries especially in the Niger Delta State calls for attention and review by the environmental authorities on the threats they pose to the environment. Some of the major breweries in the state are located near to the River Niger. The river is key to the sustenance of life in the area. Fig. 3 explains the sources of water resources. Concentration is more on the dotted lines which gives economic value of why water should be conserved and make available for use. It is worthy of note that the impact of the effluent (toxic) from these breweries will not only affect the water bodies but also the land and others as time goes on, all these component are interconnected.

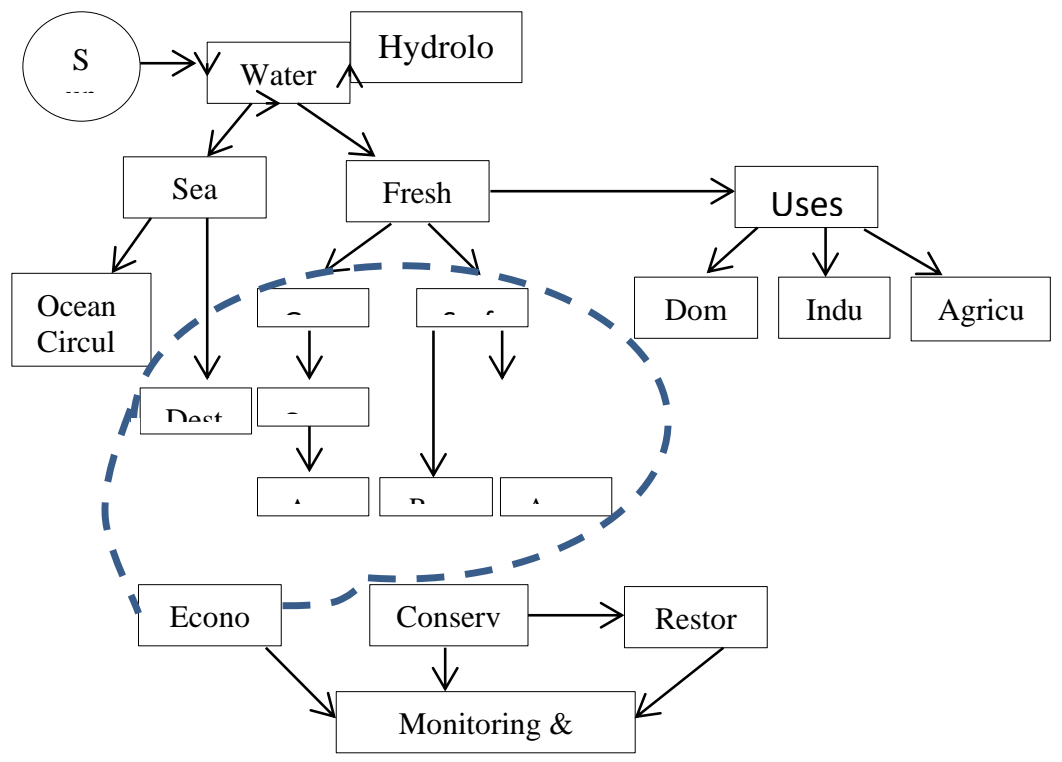

Fig. 3. Sources of water resources, authors 2020. 


\subsection{Impact on water bodies eco-zones}

Exposure effects of effluent affect micro and macrofauna, as well as humans and livestock. The major concern here is the diseases caused by the toxic components of contaminated waters where effluents are disposed of. The sources are there as there are no working treatment plants available, so, over $99 \%$ improperly treated wastewater which results in the depositing of toxics, sometimes nutrients from the large organic waste are being deposits from the brewery effluent into the water bodies. This can lead to eutrophication (caused by excess nutrient load) which also alters the water balance and energy in the structure and function of the biotic community. Sand is also deposited in the waters when the turbidity of the effluent is in excess. These multiple exposures cause organisms that can tolerate the changes in the environment to survive while others who cannot eventually die off. When this happens there is likely to be a proliferation of the tolerant organism due to a reduction in competition for resources within the environment. The changes in the dynamics of the environment by toxic effluent are thus critical and require attention by policymakers.

\subsection{Impact on the Soil eco-zones}

Sludge from some wastewater treatment plants from breweries end up being used as fertilizer to enrich or repair the soil. A contaminated sludge with toxins such as heavy metals becomes part of the soil. The danger here is that during this exposure, they become ionized to be absorbed by plants. They become accumulated in the tissues of the plant and pose a threat to humans and livestock which depend on them. The activities of microorganisms in the soil are likely to be affected due to the presence of these toxic chemicals. A substantial amount of wastewater is usually accompanied by large discharge in the form of brines. Galadima et al, [22] also supported that constituents found includes sodium, calcium, ammonia, boron, trace metals plus high total dissolved solids (TDS) and they penetrate into the soil.

\subsection{Impact on air quality}

Exposure of high biological oxygen demand leads to the generation of pungent smells as the components react and methane builds up. Gases such as hydrogen sulphide also from solid wastes unite to form this. A study revealed in a comparative analysis by Ukpere et al,[23] emission levels in Lagos and ND were higher than FEPA [24] limits for CO-10ppm, $\mathrm{SO}_{2}-0.01 \mathrm{ppm}$ and $\mathrm{NO}_{2}-0.06 \mathrm{ppm}$ in consideration with other common particles such as $\mathrm{PM}_{10}, \mathrm{PM}_{2.5}$, PAHs, dioxins PAHs, plus heavy metals but flared gas represented $12.7 \%$ and ND was a larger contributor. The bad smells could make the inhabitants in the locality very uncomfortable thereby affecting their health negatively.

\subsection{Impact on human and ecosystem eco-zones}

The buildup of toxins which leads to an increase in microbial pathogens leads to illnesses in humans living close to the point source which could be rivers or land. Nigerian largest spills was 200,000 barrels of oil (8.4 million US gallons) that spilled into the Atlantic Ocean from an industrial facility that damaged about 340 hectares of mangrove Nwilo and Badejo [25]. More oil spills are on-going as shown in the graphic Fig. 5. 
Waters in these areas drawn for drinking and for the doing several household chores exposes humans, pets and garden plants to these chemicals. Several waterborne diseases could result from this. Disease transmitting organisms such as freshwater snails and mosquitoes may contribute to several health hazards.

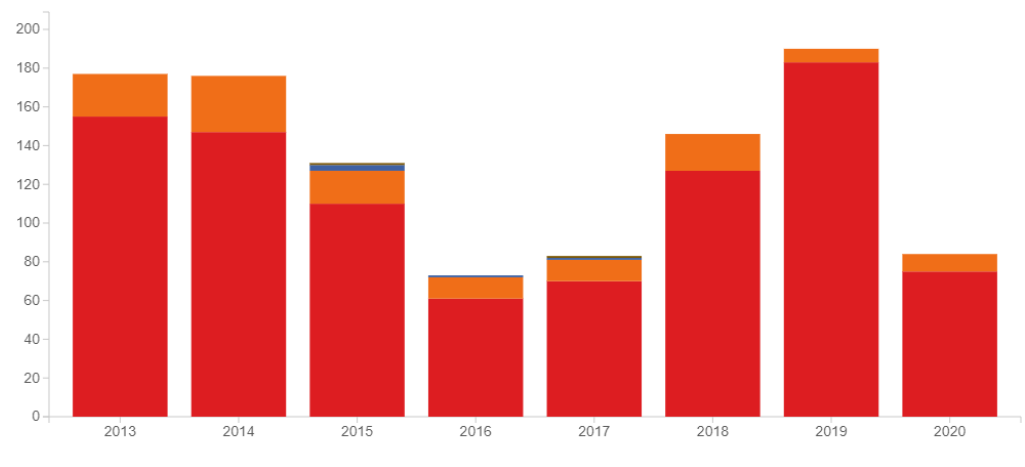

Fig. 5. Oil spills by facilities and sabotage in Delta eco-zones [26].

\subsection{Socio-economic conditions}

Above $80 \%$ of communities in Niger delta depends on the local produce such as peasant farming, fishing and logging of woods for economic sustenance. The area is now badly shaped ecologically due to multiple exposures to anthropological activities (oil drill, spills and deforestation) and does not have good access to health care systems and other basic amenities like potable water and electricity. Loss of biodiversity has altered the complex ecological balance and destructed the habitat of plant and animal species. About $70 \%$ of species are vulnerable and others are almost in danger of extinction. The quantity of species affecte is 899 species of birds, 274 mammals, 154 reptiles, 53 amphibians and 4715 species of higher plants and primates such as guenons, mangabeys, drills, chimpanzees and gorillas are considered endangered species as reported [27]. These affect the socio-economic emancipation of the people and they depend on the polluted water bodies for domestic and drinking. The last state has over 22 million populations without good access to drinkable water or municipal pipe water channelization or good sanitary systems. In both regions, most of the water sources are contaminated with benzenes from oil spills and heavy metals from effluents and municipal wastewater. A recent study by Ordinioha and Adeosun [28] showed that (37.9\%) of most common sources of drinking water was from surface water, $(61.2 \%)$ from drawers and there were an average of 17 communities in Niger Delta with water supply facilities, but only $(23.8 \%)$ of the facilities were functional and they were mostly managed. More than two third (67.9\%) tested samples were found to contain significant numbers of Escherichia coli.

\subsection{Recommendation and suggestions}

There is an unequal distribution of available water resources in Nigeria, due to the fact that the demand for water per year differs from one industrial city/ urban areas to another. Population and economic disparity is the reason behind this. Large metropolitan cities like Lagos, Onitsha, Port-Harcourt, and Kano are more prone to countless socio-economic water 
problems because they are located in riverine areas. Pollutions will be high and sources of water may be unhygienic for industrial, human and consumption. Health implication is another essential priority requiring high-level consolidation by the government management board. For sustainable water resources to be achieved, plans for the future should include decentralizing management structure and separating social activity of water according to resources viability, availability, and usage. Modern infrastructure for water storage, sewage management, and treatment has to be incorporated in economic development with an appropriate promotion of revitalizing rivers and reservoirs. Proper consultation in monitoring water scarcity especially in the Southern and far northeastern regions of the country is significantly undeniable.

\section{Conclusion}

This paper sought to highlight the importance of implementing policies to the treatment of wastewater and brewery effluent from breweries in Lagos and Niger Delta respectively. We established the wastewater treatment plants are not in good shape and does not meet the modern technological standard for effective treatment. The impact of untreated effluent on the environment affects the quality of life and at the same time deteriorate environment affecting both micro and macrofauna. These effects must be contained or eliminated by proper waste management procedures. For environmental sustainable development to occur there is a need to look at the ecological factors and issues such as the social impact of polluted water, soil and air and the livelihood of farmers and fishermen that depends on water resources for income and survival across the regions. Most freshwater bodies do not support aquatic life anymore in these places. Management failure and poor maintenance culture is responsible for the inefficient performance of wastewater treatment plants in both Niger delta and Lagos state while negligence of principal legislation such as EIA degrees 86 of 1992 confirmed this position. Our lifestyles contribute far more of the multiple effects and we have poor mechanisms to avoid exposure. Strong environmental regulations should be enacted and enforced especially for breweries and refineries operating near the Niger Rivers of Nigeria. To quantify these effects will require further empirical studies on the components of effluents and the quality of life of the inhabitants and their interactions (ecosystem) especially in both states. A significant amount of hazardous compounds discharging in Lagos will continue to further environmental deterioration and diversity loss as it remains unchecked. Above all, preventive and remedial actions should be placed as a priority for the survival of the third most cherished delta in the world and the commercial centre of Nigeria.

\section{Acknowledgements}

This study was prepared by the two authors as part of their academic research work. The authors are grateful to those whose works were referenced in this study.

\section{References}

1. I. A. Shiklomanov (1999). World water resources: modern assessment and outlook for the 21 st century. Hydrological Institute, Saint Petersburg. 
2. AQUASTAT (2019). Food and Agriculture Organization of the United Nations (FAO): Information System on Water and Agriculture.

3. J.I. Adamu (2020) Overview of the 2020 seasonal Rainfall Prediction, Nigerian Meteorological Agency

4. J.A.Veil, M.G. Puder, D.Elcock, and J.R. Redweik Jr. (2004) A white paper describing produced water from production of crude oil, natural gas, and coal bed methane. US DOE W-31-109-Eng-38

5. R.A Suleimanov (1995) Conditions of waste fluid accumulation at petrochemical and processing enterprises and prevention of their harm to water bodies Meditsina Trudai Promyshlennaia Ekologiia 12:31-36

6. A.A Kadafa, M.P Zakaria, F.Othman (2012) Oil Spillage and Pollution in Nigeria: Organizational Management and Institutional Framework. J Environ Earth Sci 2:22-30

7. A.C Marcus, O.A Ekpete (2014) Impact of discharged process wastewater from an oil refinery on the physicochemical quality of a receiving waterbody in rivers state. Nigeria IOSR Journal of Applied Chemistry (IOSR-JAC) 7(12):1-8

8. D.A. Okpara, H.C.Oruche and M.B. Offiong. (2019) Emerging solid waste leachate pollutants and brewing effluent on delta eco-zones; Impact on environmental resources sustainability, a case of Niger Delta Nigeria IOP Conference Series: Earth and Environmental Science, Volume 398, International Conference on Resources and Environment Sciences 8-10 August 2019, Jeju Island, South Korea.

9. D.A.Okpara, M.D. Kharlamova (2018) the anthropogenic effects of oil exploration on ecological forest; a paradox for agriculture and environmental sustainability in Niger delta region, Nigeria. The Journal of Food, Agriculture and Environment (JFAE) http://agris.fao.org/agris-search/search.do?recordID=FI2018100002

10. D.A. Okpara,M.B. Offiong [2020] Morphodynamics of river and coastal transport of sediments in mega delta basin, Niger Delta Nigeria, January 2020 IOP Conference Series Earth and Environmental Science 424:012010 DOI: 10.1088/17551315/424/1/012010

11. L. Fillaudeau, P. Blanpain-Avet, \& G. Daufin, (2006). Water, wastewater and waste management in brewing industries. Journal of cleaner production, 14(5), 463-471

12. D. Briggs (1999) Environmental Health: Framework and Methodologies. WHO, Geneva.

13. F. Ramukhwatho, A. Seetal, \& H. Pienaar, (2016). Water and Wastewater Management in the Malt Brewing Industry

14. A. H. Varman, and J.P. Sutherland (1994). Alcoholic beverages: I: Beer, in: Beverages - Technology, Chemistry, and Microbiology, Vol. 2, Food Products Series, 1st ed., Chapman \& Hall, London, pp. 296-361.

15. S.A Unicer (2004 \&2005), Sustainability Report, Matosinhos. http://www.unicer.pt/

16. L. Fillaudeau, P. Blanpain-Avet, \& G. Daufin (2006). Water, wastewater and waste management in brewing industries, Journal of cleaner production, 14(5), 463-471

17. F. Ramukhwatho, A. Seetal, \& H. Pienaar (2016). Water and Wastewater Management in the Malt Brewing Industry

18. W.W. Eckenfelder, (2000). Industrial Water Pollution Control. Boston: McGraw-Hill Higher Education. 
19. D.L. Ford, (1998). Toxicity Reduction-Evaluation and Control (2nd Ed.). Lancaster: Technomic Publishing Company.

20. S.J. Arceivala, (1998), Wastewater Treatment Disposal. Marcel Dekker Inc. New York: USA. $(41-42)$.

21. W. Driessen, and T. Vereijken, (2003), Recent Development in Biological Treatment of Brewing Effluent. 9th Brewing Convention, Victoria Fails, Zambia. Journal of Effluent Treatment $165-166$

22. A. Galadima, Z.N. Garba, L. Leke, M.N. Almustapha, \& I.K. Adam, (2011). Domestic Water Pollution among Local Communities in Nigeria ---- Causes and Consequences. European Journal of Scientific Research ISSN 1450-216X Vol.52 No.4 (2011), p.592603

23. D.R.T. Ukpere, A.B. Clifford, E.S.C. Ojule, \& C.R. Ottah, (2018). Impacts of Air Pollution in the Niger Delta Region of Nigeria. IIARD International Journal of Geography and Environmental Management ISSN 2504-8821 Vol. 4 No. 42018

24. FEPA (Federal Environmental Protection Agency), (1991) Guidelines for Standards for Environmental Pollution Control in Nigeria, FG Press Lagos Nigeria.pp238

25. P.C.Nwilo, \& O.T. Badejo, (2005), Oil Spill Problems and Management in the Niger Delta. International Oil Spill Conference, Miami, Florida, USA.

26. https://www.shell.com.ng/sustainability/environment/oil-spills.html retrived 24 July, 2020.

27. (NDDC) Niger Delta development commission, (2004) Regional master plan project, revised final report for biodiversity and Natural resources

28. B. Ordinioha, A. Adeosun, (2008) A survey of the community water supply of some communities in Rivers State, south-south Nigeria. The Nigerian Health Journal; 39-42 